\title{
Quantitative Estimation of Hydrogen Cyanide in Fresh and Cooked Tuber Parenchyma (Pulp) of Three Cultivars of Sweet Cassava Cultivars Grown in Some Parts of Benue State, Nigeria
}

\author{
Simon Terver Ubwa, Sunday Ogakwu Adoga, Raymond Lubem Tyohemba, \\ Tseaa Shambe* \\ Chemistry Department, Benue State University, Makurdi, Nigeria \\ Email: tshambe@bsum.edu.ng
}

Received 11 June 2015; accepted 10 July 2015; published 14 July 2015

Copyright (C) 2015 by authors and Scientific Research Publishing Inc.

This work is licensed under the Creative Commons Attribution International License (CC BY). http://creativecommons.org/licenses/by/4.0/

(c) (i) Open Access

\section{Abstract}

The amount of cyanide in fresh and cooked tuber parenchyma (pulp) of three cultivars of sweet cassava from two local government areas (LGA) of Benue state was studied. Cassava tubers were collected and carefully peeled to obtain the pulp. The fresh and boiled samples were adequately processed and treated with ninhydrin, $\mathrm{Na}_{2} \mathrm{CO}_{3}$ and $\mathrm{NaOH}$ and the absorbance of the reaction product measured using UV-Visible spectrometer after construction of a calibration graph using standard cyanide solutions. The amount of cyanide in the fresh pulp varied with differences in cultivars ranging from White Dan-Warri Cultivar: (19.87 to 28.81$) \mathrm{mg} / \mathrm{kg}$; Obasanjo cultivar: (17.23 to 28.81$) \mathrm{mg} / \mathrm{kg}$ and Red Dan-Warri Cultivar (8.23 to 19.31) $\mathrm{mg} / \mathrm{kg}$. Also, the cyanide content of cultivars from 0ju LGA was generally higher than that of the cultivars from Gwer-east LGA. Cyanide content varied with the period of the day harvested in the order: Afternoon > Evening > Morning for all cultivars. Furthermore, cooking greatly reduced the cyanide content of all the sweet cassava cultivars but boiling was more effective than roasting with the cyanide removal increasing with increase in cooking time. The cyanide content of the tuber parenchyma of the sweet cassava cultivars was very low $(<30 \mathrm{mg} / \mathrm{kg}$ ) which is in agreement with reported values for sweet cassava. However, cooking at a reasonable time interval will further reduce their cyanide levels to further safe limits.

\footnotetext{
${ }^{*}$ Corresponding author.
}

How to cite this paper: Ubwa, S.T., Adoga, S.O., Tyohemba, R.L. and Shambe, T. (2015) Quantitative Estimation of Hydrogen Cyanide in Fresh and Cooked Tuber Parenchyma (Pulp) of Three Cultivars of Sweet Cassava Cultivars Grown in Some Parts of Benue State, Nigeria. Food and Nutrition Sciences, 6, 836-844. http://dx.doi.org/10.4236/fns.2015.610087 


\section{Keywords}

\section{Cyanide Content, Cassava, Roasted, Boiled, Harvesting Time}

\section{Introduction}

Cassava (Manihot esculenta Crantz) is a root crop from the family of Euphorbiaceae which has its origin from Latin America and was later introduced into Asia and Africa [1]. It is now grown worldwide as a staple food due to its advantages over other cereal crops like rice and maize; hence it is cultivated in areas (especially SubSaharan Africa) with degraded resource base, uncertain rainfall and weak market infrastructure. Its ability to be drought resistant makes it the most apposite for food during periods of drought and famine [2]. It has been reported that half of the World's production of cassava is derived from Africa with Nigeria accounting for about $70 \%$ of its harvest output in this region [3]. The southeastern, southwestern and central zones are the main cassava belts where it is typically intercropped with other crops [4].

The enormous uses of cassava throughout the globe cannot be overemphasized. However, as earlier reported by Jogensen et al. [5], the foremost shortcoming associated with cassava crop are: low protein content, rapid tuber perishability following harvest and high content of cyanogenic glycosides. The cyanogenic glycosides are a group of secondary metabolites in plants that yield cyanide upon enzyamatic metabolism which have been implicated in their role as herbivore deterrents and as transportable forms of reduced nitrogen [6]. Approximately 25 cyanogenic glycosides have been identified and the major ones in edible parts of plants are: amydalin, dhurrin, linamarin, lotaustralin, prunasin and taxiphyllin being present in shoots, leaves and fruits of plants such as: almonds, sorghum, cassava, lima beans, stone fruit and bamboo shoots [1]. In cassava, the disruption of the cell structure by peeling and slicing initiates cyanogenisis with subsequent release of hydrogen cyanide [1] [6]. The major cyanogenic glycoside in cassava is linamarin while methyl linamarin (lotaustralin) is also present in minute quantity alongside the enzyme linamarinase. When the vacuole in the cassava cell is ruptured, there is release of linamarin which rapidly hydrolyses through enzymatic catalysis by the enzyme linamarinase to glucose and acetone cyanohydrins while lotaustralin is hydrolysed to a related cyanoydrin and glucose [1] [7]. Since acetone cyanohydrins is an unstable intermediate, it spontaneously decomposes to acetone and hydrogen cyanide; normally at $\mathrm{pH}>5.0$ or temperatures $>35^{\circ} \mathrm{C}[1]$ [6].

Inadequate processing could result to toxicity from the residual hydrogen cyanide released from the cyanogenisis. Various ailments from cyanide toxicity have been reported in human among which include: vomiting, diarrhea, dizziness, headache, stomach pains, rapid respiration, drop in blood pressure, mental confusion, rapid pulse rate, twitching, convulsion and tropical ataxic neuropathy [1] [8]-[10]. The cyanide content of cassava differs with a number of conditions such as: species varieties, harvesting time and season. Sweet varieties of cassava (low cyanide content) have been reported to contain as much as $15-50 \mathrm{mg} / \mathrm{kg}$ hydrogen cyanide on fresh weight basis and can be processed by roasting, boiling or baking whereas the bitter varieties (high cyanide content) require more extensive processing such as heap fermentation [1]. However, during seasons of drought, cyanide content of both sweet and bitter varieties is increased markedly [11]. Generally, values from 15 to 400 $\mathrm{mg} / \mathrm{kg}$ of hydrocyanic acid in cassava roots on a fresh weight basis have been reported in literature but approximately 50 to $60 \mathrm{mg}$ of free cyanide from cassava and its processed products constitute a lethal dose for an adult man [1].

Following the adverse effects associated with cyanide content in cassava even after processing, the present study investigated the cyanide content in the tuber parenchyma (pulp) of fresh sweet cassava cultivars grown in Benue State Nigeria where the crop is greatly consumed. It further evaluates the effect of time of harvest, roasting and boiling on the residual cyanide content in the pulp of the fresh tubers of these cultivars

\section{Materials and Method}

\subsection{Materials}

All reagents used in this study are of analytical grade. Ninhydrin (Reidel-de Haen, AG D-3016), Potassium Cyanide (B. No. 8847, Pharmacos Ltd., Southend-on-sea, Essex England), Sodium Chloride (UN 1823, J.T. 
Baker, daventer, Holland), $\mathrm{NaHCO}_{3}$ (BH-15 ITD, BDH Laboratories, England and $\mathrm{Na}_{2} \mathrm{CO}_{3}$. Digital Environment thermometer (VC-500, Zhijian, China), UV/Visible Spectrometer (SURGISPEC SM 753, Surgical Medical, England).

\subsection{Sample Collection}

A purposive sampling strategy was used in selecting the site to be studied. This was done according to interaction with farmers/villagers to know areas that are involved in large production of the cassava specie under studied. Samples were taken in triplicates from three different farms in the local government areas. Fresh cassava roots were obtained from three different locations (i.e. Ebonda-Ukpa-A, Ainu-Ette-B and Ogengeng-C and, Mbaba-Taraku-D, Mbaapen-Mbaakencha-Taraku-E and Aliade-F) in Oju and Gwer-East local government areas of Benue state respectively.

\subsection{Sample Preparation for Total Cyanogens Determination}

The cassava root sample were ground and homogenized in a pestle and mortar after removal of peels. $0.1 \mathrm{mg}$ of the ground sample was transferred in a test tube, and $5 \mathrm{~mL}$ of $0.1 \% \mathrm{NaHCO}_{3}$ added. The samples were sonicated for $20 \mathrm{~min}$ in a water bath. $1 \mathrm{~mL}$ of the mixture measured by use of automatic pipette was centrifuged at $10000 \mathrm{rpm}$ for 10 minutes and two aliquots of supernatant ( $2 \mathrm{~mL}$ each) were taken for spectrophotometric analysis [12].

\subsection{Estimation of Cyanide in Cassava Samples}

The cyanide level in cassava samples was determined according to the method described by Surleva et al. [12]. A calibration graph was first constructed where standard solutions of $\mathrm{CN}^{-}$at concentrations of $0.02,0.04,0.08$, 0.1 and $0.2 \mu \mathrm{g} / \mathrm{mL}$ (which is within the linear range) were prepared by adding appropriate volumes of cyanide solutions at concentration of $20 \mu \mathrm{g} \mathrm{CN}^{-} / \mathrm{mL}$ to $1 \mathrm{~mL}$ of $2 \% \mathrm{Na}_{2} \mathrm{CO}_{3}$. Furthermore, $0.5 \mathrm{~mL}$ of ninhydrin solution ( $5 \mathrm{mg} / \mathrm{mL}$ ninhydrin in $2 \% \mathrm{NaOH}$ ) was added to each standard cyanide solution. The mixture was homogenized and incubated for 15 minutes for colour development. Similarly, the blank was prepared essentially the same as above except that instead of $1 \mathrm{~mL} 2 \% \mathrm{Na}_{2} \mathrm{CO}_{3}$ containing $\mathrm{CN}^{-}, 1 \mathrm{~mL}$ of $2 \% \mathrm{Na}_{2} \mathrm{CO}_{3}$ without $\mathrm{CN}^{-}$was added. UV-Visible absorption of the reaction product (Cyanide-ninhydrin adduct) of the different concentrations of cyanide was measured.

Total cyanogens in the samples were determined by standard addition method to remove matrix, reagent instability and colour reaction product interferences. Two aliquots $(1 \mathrm{~mL})$ of cyanide and sample extract were taken. To each second aliquot, a standard addition of cyanide was made and $0.5 \mathrm{~mL}$ ninhydrin reagent added. The absorbance of the samples was recorded at $485 \mathrm{~nm}$ against a blank containing $1 \mathrm{~mL}$ of $2 \% \mathrm{NaOH}$ and 0.5 $\mathrm{mL}$ of ninhydrin reagent.

\subsection{Statistical Analysis}

The one way analysis of variance was used to compare the means of the variables. This was achieved through the general model program SAS and the Fisher multiple comparison procedures and the least significant difference (LSD) at $\mathrm{p}<0.05$ was determined.

\section{Results and Discussion}

\subsection{Variation in Total Cyanide Content of Tuber Parenchyma of the Studied Cultivars}

The cyanide content in fresh tuber parenchyma (pulp) of the studied cultivars of sweet cassava is presented in Table 1. The concentration of cyanide in the tuber parenchyma of the cultivars grown in Oju and Gwer-East Local Government Areas (LGA) of Benue State varied among cultivars and locations. The variation in cyanide content of the cultivars followed a particular trend. The White Dan-Wari cultivar recorded the highest cyanide content (19.87 to $28.81 \mathrm{mg} / \mathrm{kg}$ ), followed by the Obasanjo Cultivar (17.23 to $23.43 \mathrm{mg} / \mathrm{kg}$ ) and Red Dan-wari cultivar (8.23 to $19.31 \mathrm{mg} / \mathrm{kg}$ ). The only exception for this trend was observed at location D where the highest concentration of cyanide $(19.62 \mathrm{mg} / \mathrm{kg})$ was recorded in the Obasanjo Cultivar. Similarly, there was a general trend in the cyanide content of the sweet cassava cultivars based on the two major locations (LGAs). The cya- 
Table 1. Cyanide content in fresh pulp of cassava cultivars at various farms (mg/kg).

\begin{tabular}{|c|c|c|c|}
\hline Farm Code & Obasanjo Cultivar & Red Dan-Warri Cultivar & White Dan-Warri Cultivar \\
\hline A & $23.43 \pm 0.23^{\mathrm{a}}$ & $16.20 \pm 0.23^{\mathrm{a}}$ & $28.81 \pm 0.65^{\mathrm{a}}$ \\
\hline B & $24.74 \pm 0.17^{\mathrm{a}}$ & $19.31 \pm 2.23^{\mathrm{a}}$ & $26.74 \pm 0.27^{\mathrm{a}}$ \\
\hline $\mathrm{C}$ & $24.34 \pm 0.36^{\mathrm{a}}$ & $18.57 \pm 1.59^{\mathrm{a}}$ & $27.54 \pm 0.53^{\mathrm{a}}$ \\
\hline $\mathrm{D}$ & $19.62 \pm 2.71^{\mathrm{b}}$ & $8.16 \pm 0.77^{\mathrm{b}}$ & $18.56 \pm 1.20^{\mathrm{b}}$ \\
\hline $\mathrm{E}$ & $19.81 \pm 1.46^{\mathrm{b}}$ & $9.47 \pm 1.08^{b}$ & $20.31 \pm 1.45^{\mathrm{b}}$ \\
\hline $\mathrm{F}$ & $17.88 \pm 0.61^{\mathrm{b}}$ & $8.23 \pm 1.07^{b}$ & $19.87 \pm 1.44^{\mathrm{b}}$ \\
\hline
\end{tabular}

*(Values are means of triplicate determination \pm SD) Means in the same column with different superscripts are significantly different at (p < 0.05).

nide content in the cultivars from Oju LGA was higher than that of the same cultivars from Gwer-East LGA. The mean levels of cyanide in the studied cultivars in samples A, B and C (Oju LGA) was in the range of 16.20 to $28.81 \mathrm{mg} / \mathrm{kg}$ while the cyanide content in samples D, E and F (Gwer-East LGA) was in the range of 8.16 to 20.31) $\mathrm{mg} / \mathrm{kg}$. The amount of cyanide in plants is well-known to differ with ecological and edaphic condition [11] [13].

The cyanide content of these cassava cultivars is affirmative of their classification as being sweet with all containing $<50 \mathrm{ppm}$ of cyanide. Sweet varieties of cassava have been reported to contain $<50 \mathrm{mg} / \mathrm{kg}$ or between 15 to $50 \mathrm{mg} / \mathrm{kg}$ of linamarin calculated as $\mathrm{mg} \mathrm{CN} / \mathrm{kg}$ of edible portions on fresh weight basis [1] [14] and such levels have been said to be harmless [15]. Hence the cultivars reported in the present study are safe for consumption. However, only the cyanide content of Red Dan-wari cultivar in Gwer-East location (samples D, E and F) are below the World Health Organization's recommended safe limit of 10 ppm for cassava flour [16]. Ezeigbo et al. [17] have reported cyanide level of $36.65 \mathrm{mg} / \mathrm{kg}$ in sweet cassava cultivar in Abia State, Nigeria which is higher than the findings in the studied cultivars. The amount of cyanide in fresh pulp of some Nigerian cultivars is much higher than the amount obtained in sweet cultivars in the present study. Levels as high as; 49.89 $62.57 \mathrm{mg} / \mathrm{kg}, 437.4 \mathrm{mg} / \mathrm{kg}$ and $304.6 \mathrm{mg} / 100 \mathrm{~g}$ [17]-[19] have been documented for some bitter cassava varieties in Nigeria. Studies on the cyanide levels in cassava in some South Pacific Islands countries revealed cyanide content of $13 \mathrm{mg} / \mathrm{kg}$ in Fijian cassava, 18 to $15 \mathrm{mg} / \mathrm{kg}$ in Tonga and 26 to $78 \mathrm{mg} / \mathrm{kg}$ in cassava samples in Vanuatu [20]. The levels of cyanide obtained in the present study also falls within this range. There was a significant difference $\mathrm{p}<0.05$ in the cyanide content between the two locations but no significant difference existed in the cyanide content at the samples collected at the farms within the same location.

\subsection{Effect of Daily Harvesting Time on the Cyanide Content of the Fresh Tuber Parenchyma of Sweet Cassava Cultivars}

The effect of this practice on the cyanide content of cassava is presented in Figures 1-3. The cyanide content of the harvested tuber parenchyma varied from morning through evening. The levels of cyanide in the samples harvested in the afternoon recorded all time highest in all the cultivars. This was followed by the cyanide content of cultivars harvested in the evening. The amount of cyanide in the fresh parenchyma of samples harvested in the morning was the least in all the studied samples. It has been reported that cyanogenisis in plants is induced when there is damage to the plant cell which releases the enzymes which cause the release of cyanide from the glycoside complex. This condition can be initiated by weather conditions such as drought and frost [21]. Earlier research has also indicated that photodecomposition can occur when ultraviolet radiation from the sun breaks down cyanide complex thus its greater availability at higher temperatures when the cassava is harvested at such times of the day [22]. Furthermore, relevant environmental factors such as high temperatures, crushing, wilting, freezing and water stress have been implicated as conditions that damage relevant plant species, reduce protein synthesis and inhibit $\beta$-cyanoalanine synthase potentially increasing the risk of cyanogenesis [23]. Cyanogenic glycosides may become readily available during the day at bright sunlight (higher temperatures) when the photosynthetic capacity of the plant is at maximum and are thus reserved in the plant since they are secondary metabolites and their major activity is being suspended at this time [20] [24]. 


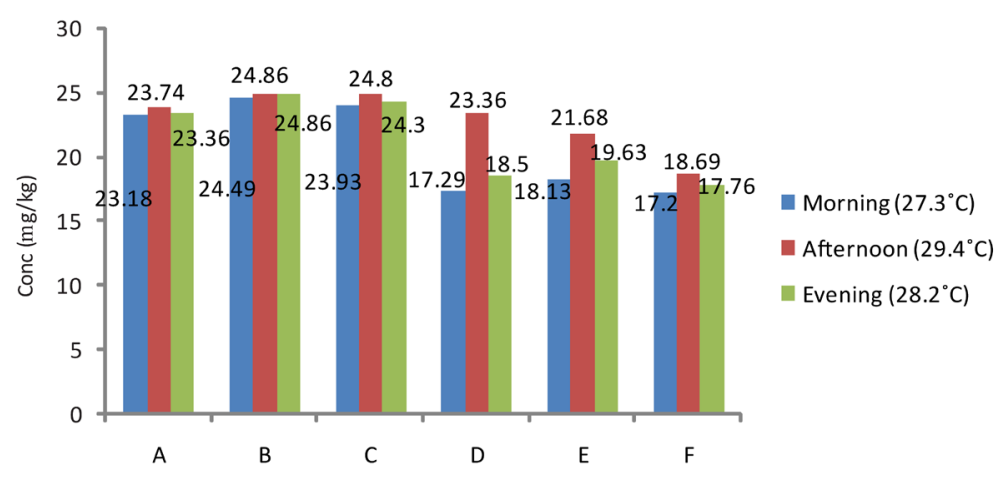

Figure 1. Effect of daily harvesting time on the cyanide content of fresh pulp in Obasanjo Cultivar from different locations.

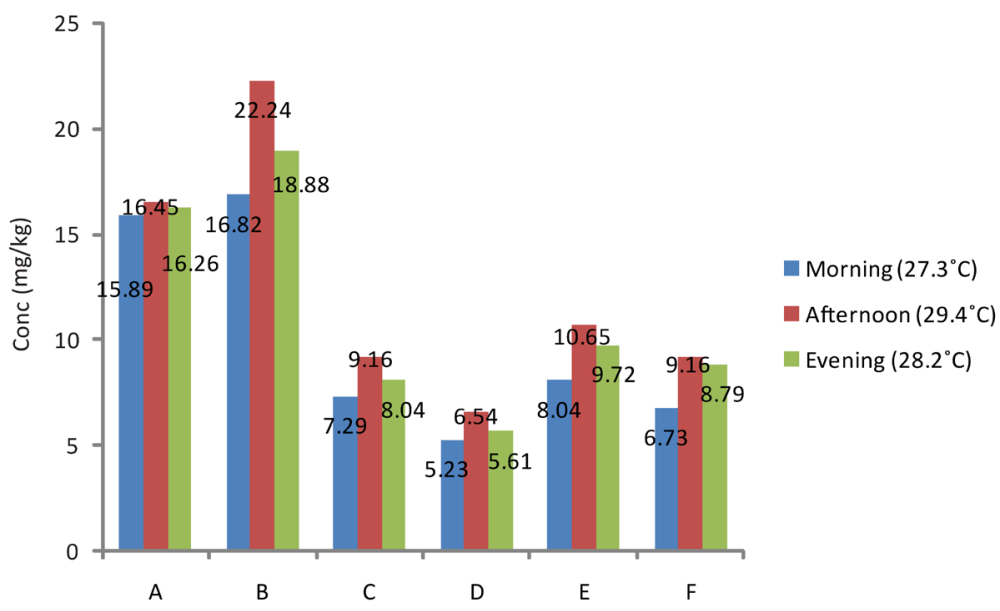

Figure 2. Effect of daily harvesting time on the cyanide content of fresh pulp in Red Dan-Warri Cultivar from different locations.

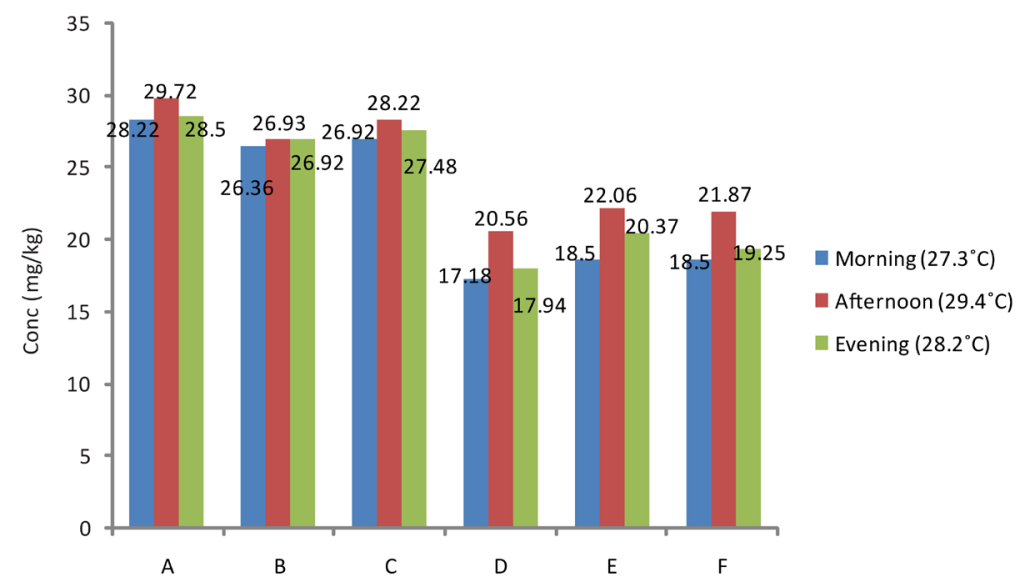

Figure 3. Effect of daily harvesting time on the cyanide content of fresh pulp in White Dan-Warri Cultivar from different locations.

\subsection{Effect of Heating on the Cyanide Content}

The effect of cooking on the cyanide content of the sweet cassava cultivars is present in Figures 4-6. Generally, the cyanide content decreased with increase in cooking time. In all the cultivars, roasting recorded the least decrease in cyanide content. However, on boiling at different time intervals (25, 35 and 45) minutes respectively, 


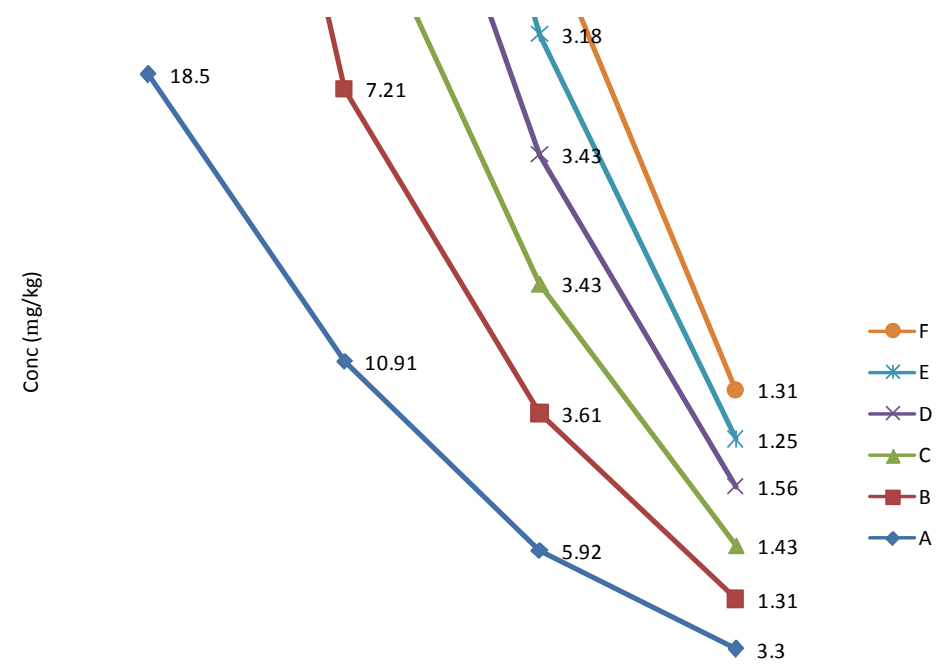

\begin{tabular}{cccc}
\hline ROASTED & $\begin{array}{c}\text { BOILED @ 25 } \\
\text { MUNITES }\end{array}$ & $\begin{array}{c}\text { BOILED @ 35 } \\
\text { MUNITES }\end{array}$ & $\begin{array}{c}\text { BOILED @ 45 } \\
\text { MUNITES }\end{array}$ \\
&
\end{tabular}

Figure 4. Variation in cyanide content in Obasanjo Cultivar on heating.

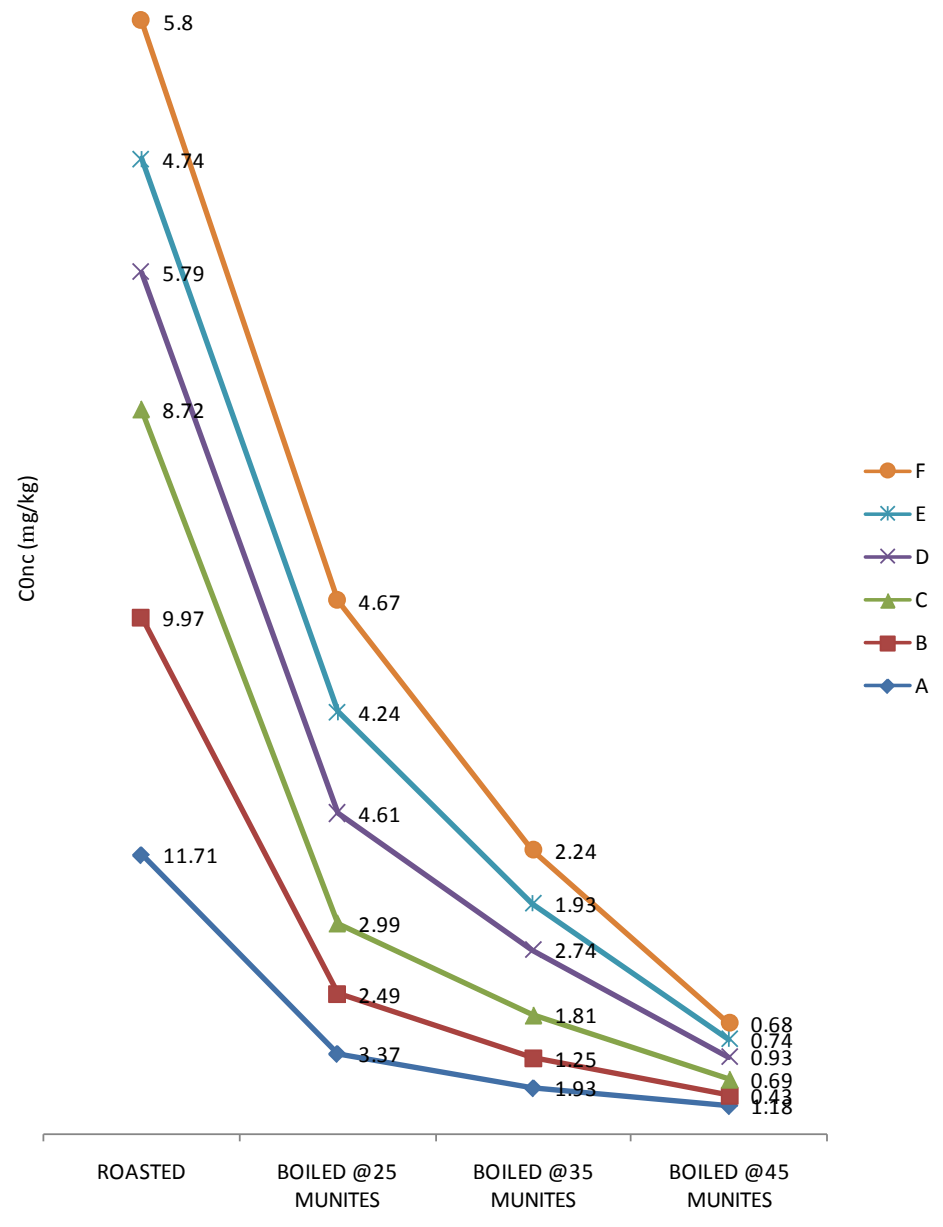

Figure 5. Variation in cyanide content in Red Dan-Warri Cultivar on heating. 


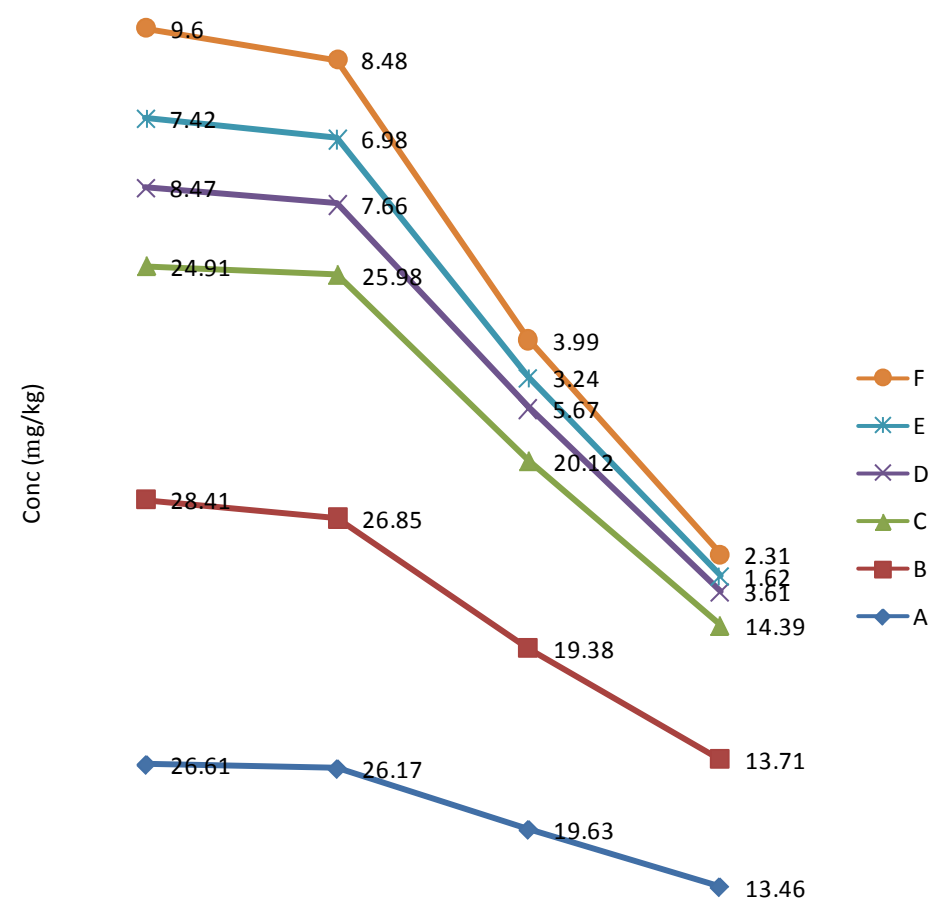

\begin{tabular}{cccc}
\hline ROASTED & $\begin{array}{c}\text { BOILED @25 } \\
\text { MUNITES }\end{array}$ & $\begin{array}{c}\text { BOILED @ 35 } \\
\text { MUNITES }\end{array}$ & $\begin{array}{c}\text { BOILED @45 } \\
\text { MUNITES }\end{array}$
\end{tabular}

Figure 6. Variation in cyanide content in White Dan-Warri Cultivar on heating.

there was a steady decrease in the cyanide content of the tuber parenchyma as the boiling time increased. The percentage removal of cyanide on roasting was in the range of 5.88\% - 63.47\%, 9.58\% - 62.24\% and 27.72\% 53.04\% for white Dan-wari, Obasanjo and Red Dan-wari cultivars respectively. Also, boiling of this fresh tuber parenchyma of the sweet cassava cultivars reduced removed their cyanide content more than roasting. Boiling at different time intervals of 25, 35 and 45 minutes was able to remove the cyanide content of these samples in the order of 5.49\% - 87.11\%, 26.94\% - 93.53\% and 47.75\% - 97.77\% for white Dan-wari, Obasanjo and Red Danwari cultivars respectively. There is a consistent trend of cyanide removal upon heat treatment in the order Red Dan-wari > Obasanjo > White Dan-wari. The implication is that the White Dan-wari cultivar needs to be roasted or boiled for longer time to reduce the amount of cyanide before consumption. The effect of cooking time on the percentage cyanide removal is also reported in related literature [25]. Reduction in cyanogens potential of up to $70 \%$ and over 90\% have been documented in earlier reports [25] [26]. The possibility of retention of cyanogenic glycoside levels in cassava after cooking is as a result of the destruction of linamarase enzyme after cooking and thus making contact with its substrate insufficient for thorough detoxification [14] although the method of cooking have been recommended as a method of processing sweet cassava [27].

\section{Conclusion}

In this study, the cyanide content of fresh tuber parenchyma of sweet cassava cultivars showed that they are very innocuous: having cyanide in amounts $<30 \mathrm{mg} / \mathrm{kg}$ which is in agreement with documented literature for sweet cassava varieties. There were however variations in the cyanide content with difference in cultivars and locations. White Dan-wari cultivar had the highest content of cyanide while the least amount of cyanide was contained in the Red Dan-war cultivar. The amount of cyanide present in all the cassava cultivars from Gwer-east LGA is lower than what was obtained from cultivars from Oju LGA. On heating (cooking), the cyanide content of these cultivars was removed to various extents. However, wet heating (boiling) was more efficient in cyanide 
removal than dry heating (roasting) but the extent of cyanide removal on boiling increased with boiling time. The finding from this work indicates that sweet (low cyanide) cultivars in the study area are benign and can be processed easily for cyanide reduction. Furthermore, good agronomical practices will increase the yield of these sweet cultivars [28] which have been shown to have minimal cyanide content and their cultivation encouraged. This would reduce the risk that is usually associated with high content of residual cyanide that remains during processing of the bitter cultivars especially during dry season (January-June) when water scarcity could lead to inadequate processing of cassava products to safer residual limits. The period is also characterized by scarcity of yams and sweet potatoes which are often roasted and eaten on farms while working. The Sweet cultivars used here can substitute these readily available crops. Processed high cyanide cassava products often sold in local markets ("akpu" and "gari") should always be monitored by Food regulatory agencies to ensure that the quality or cyanide content in them meets the requirement for human consumption.

\section{References}

[1] Food Standards Australia New Zealand (FSANZ) (2005) Cyanogenic Glycosides in Cassava and Bamboo Shoots: A Human Health Risk Assessment. Technical Report Series No. 28. http://www.foodstandards.gov.au

[2] Nweke, F.I., Spencer, D.S.C. and Lynam, J.K. (2001) The Cassava Transformation: Africa’s Best Kept Secret. Michigan State University Press, East Lansing.

[3] International Fund for Agricultural Development (IFAD) and Food and Agriculture Organization of the United Nations (FAO) (2000) The World Cassava Economy: Facts and Outlook. Rome. 31 pp.

[4] Nweke, F. (2004) New Challenges in the Cassava Transformation in Nigeria and Ghana. EPTD Discussion Paper No. 118. International Food Policy Research Institute, Washington DC.

[5] Jogensen, K., Bak, S., Busk, P.K., Sorensen, C., Olsen, C.K., Puonti-Kaerlas, J. and Moller, B.L. (2005) Cassava Plant with a Depleted Cyanogenic Glucoside Content in Leaves and Tubers. Distribution of Cyanogenic Glucosides, Their Sites of Synthesis and Transport, and Blockage of the Biosynthesis by RNA Interferences Technology. Plant Physiology, 139, 363-374. http://dx.doi.org/10.1104/pp.105.065904

[6] White, W.L.B., Arias-Garzon, D.I., McMahon, J.M. and Sayre, R.T. (1998) The Role of Hydronitrile Lyase in Root Cyanide Production. Plant Physiology, 116, 1219-1225. http://dx.doi.org/10.1104/pp.116.4.1219

[7] McMahon, J., White, W. and Sayre, R.T. (1995) Cyanogenesis in Cassava (Manihot esculenta Crantz). Journal of Experimental Botany, 46, 731-741. http://dx.doi.org/10.1093/jxb/46.7.731

[8] Oluwale, O.S.A., Onabolu, A.O., Link, H. and Roseling, H. (2000) Persistence of Tropical Ataxic Neuropathy in a Nigerian Community. Journal of Neurology, Neurosurgery, and Psychiatry, 69, 96-101.

http://dx.doi.org/10.1136/jnnp.69.1.96

[9] Rosling, H., Mlingi, N., Tylleskar, T. and Babea, M. (1993) Casual Mechanisms behind Human Diseases Induced by Cyanide Exposure from Cassava. In: Roca, W. and Thro, A., Eds., Proceedings of the First International Scientific Meeting of the Cassava Biotechnology Network, Centro International de Agricultura Tropica, Cali, 366-375.

[10] Osuntokun, B.O. (1981) Cassava Diet, Chronic Cyanide Intoxication and Neuropathy in Nigerian Africans. World Reviews in Nutrition and Diet, 36, 141-827. http://dx.doi.org/10.1159/000393156

[11] Bokanga, M., Ekanayake, I.J., Dixon, A.G., Cyanogenic, O. and Porto, M.C.M. (1994) Genotype-Environment Interactions for Potential in Cassava. Acta Horticulturae, 375, 131-139.

[12] Surleva, A., Zahraria, M., Ion, L., Gradinaru, R.V., Drochioiu, G. and Mangalagiu, I. (2013) Ninhydrin-Based Spectrophotometric Assays of Trace Cyanide. Acta Chemica IASA, 21, 57-70.

[13] Burns, A., Gleadow, R., Cliff, J., Zacarias, A. and Cavagnaro, T. (2010) Cassava: The Drought, War and Famine Crop in a Changing World. Sustainability, 2, 3572-3607.

[14] Jansz, E.R. and Uluwaduge, D.I. (1997) Biochemical Aspects of Cassava (Manihot esculenta Crantz) with Special Emphasis on Cyanogenic Glucosides-A Review. Journal of the National Science Council of Sri Lanka, 25, 1-24.

[15] Burns, A.E., Gleadow, R.M. and Zacarias, A.M. (2012) Variations in the Chemical Composition of Cassava (Manihot esculenta Crantz) Leaves and Roots as Affected by Genotypic and Environmental Variation. Journal of Agriculture and Food Chemistry, 60, 4946-4956. http://dx.doi.org/10.1021/jf2047288

[16] FAO/WHO (1995) Codex Standards for Edible Cassava Flour. In: Joint FAO/WHO Food Standards Programme, Codex Standards 176-1989, Codex Alimentarius Commission; Food and Agricultural Organization and World Health Organization of the United Nations, Rome.

[17] Ezeigbo, O.R., Ukpabi, C.F., Ike-Amadi, C.A. and Ekkaiko, M.U. (2015) Determination of Starch and Cyanide Content of Different Species of Fresh Cassava Tuber in Abia State, Nigeria. British Biotechnology Journal, 6, 10-15. 
http://dx.doi.org/10.9734/BBJ/2015/15297

[18] Asegbeloyin, J.N. and Onyimonyi, A.E. (2007) The Effect of Different Processing Methods on the Residual Cyanide of “Garri”. Pakistan Journal of Nutrition, 6, 163-166. http://dx.doi.org/10.3923/pjn.2007.163.166

[19] Anhwange, B.A., Asemave, K., Ikyenge, B.A. and Oklo, D.A. (2011) Hydrogen Cyanide Content of Manihot utilissima, Colocasia esculenta, Dioscorea bulbifera and Dioscorea domemtorum Tubers Found in Benue State. International Journal of Chemistry, 3, 69-71. http://dx.doi.org/10.5539/ijc.v3n4p69

[20] Dolodolotawake, U. and Aalbersberg, W.G.L. (2011) Cyanide Content of Cassava and Some of Its Products in Some South Pacific Island Countries. Professional and Technical Reports, University of South Pacific (USP) Electronic Research Repository. http://repository.usp.ac.fj/id/eprint/4852

[21] Colorado State University Extension (2003) Genetics and Evolutionary Ecology of White Clover (Trifolium repens). Colorado State University Cooperative Extension Web Manager. www.ext.colostate.edu

[22] MERG, Mining Environment Research Group (2001) Cyanide-The Facts. Geoscience Information and Sales, Yukon Geological Survey, Department of Energy, Mines and Resources, Yukon. http://www.geology.gov.yk.ca/pdf/MPERG_2001_2.pdf

[23] The MERCK Veterinary Manual (2015) Overview of Cyanide Poisoning. Merck Sharp and Dohme Corp; a Subsidiary of Merck and Co., Inc., White House Station. http://www.merckvetmanual.com/mvm/toxicology/cyanide_poisoning/overview_of_cyanide_poisoning.html

[24] Ohio State University (2003) Researchers Get to the Root of Cassava’s Cyanide-Producing Abilities. http://researchnews.osu.edu/archive/cassava.htm

[25] Hidayat, A., Zuraida, N. and Hanarida, I. ((2002) The Cyanogenic Potential of Roots and Leaves of Ninety Nine Cassava Cultivars. Indonesian Journal of Agricultural Science, 3, 25-32.

[26] Ngudi, D.D., Kuo, Y.H. and Lambein, F. (2003) Cassava Cyanogens and Free Amino Acids in Raw and Cooked Leaves. Food and Chemical Toxicology, 41, 1193-1197. http://dx.doi.org/10.1016/S0278-6915(03)00111-X

[27] FRI, Food Research Institute (2012) Work Package 4: Ensuring the Safety and Quality of Processed Cassava Products in Market-Oriented Production: Report on the Review of Previous Experiences and Works on Cyanogenic Glycosides in Cassava Processing. CSIR-FRI/NRI Cassava Gmarket Project, Council for Scientific and Industrial, Ghana.

[28] Cock, J.H. (1982) Cassava: A Basic Energy Source in the Tropics. Science, 218, 755-762. http://dx.doi.org/10.1126/science.7134971 